\title{
INTERTEMPORAL SUBSTITUTION AND THE LIQUIDITY EFFECT IN A STICKY PRICE MODEL ${ }^{(*)}$
}

\author{
J. Andrés ${ }^{(1)}$, J.D. López-Salido ${ }^{(2)}$ and J. Vallés ${ }^{(2)}$ \\ (1) Banco de España and Universidad de Valencia, \\ (2) Banco de España, Research Department.
}

September 1999

\begin{abstract}
The liquidity effect, defined as a decrease in nominal interest rates in response to a monetary expansion, is a major stylized fact of the business cycle. This paper seeks to understand under what conditions such an effect can be explained in a general equilibrium model with sticky prices and capital adjustment costs. The paper first confirms that, with separable preferences, a low degree of intertemporal substitution in consumption is a necessary condition for the existence of the liquidity effect. Contrary to this result, in a model with non-separable preferences and capital accumulation it takes an implausibly high degree of intertemporal substitution to produce a liquidity effect. The robustness of these results to alternative degrees of nominal rigidities, money demand properties and real rigidities is also analyzed.
\end{abstract}

Keywords: intertemporal substitution, liquidity effect, price and capital adjustment costs.

JEL Classification: E32, E43.

Corresponding author: Javier Vallés, Research Department Banco de España, Alcalá 50, 28014 Madrid, Spain. E-mail: valles@bde.es

(*) We owe special thanks to Larry Christiano, Jordi Galí, Robert Kollmann and Sergio Rebelo for very helpful comments and suggestions. We also thank Isabel Correia, Olivier Jeanne, Albert Marcet, Stephanie Smitt-Grohé and Pedro Teles for insightful conversations, and seminar participants at Banco de Portugal, CEPR 1999 European Summer Symposium in Macroeconomics (Sintra), and the Society for Economic Dynamics 1999 Annual Meeting (Alghero) for comments. The views expressed in this paper are the authors' and do not necessarily reflect those of the Banco de España. 


\section{Introduction}

The negative correlation between money growth and the nominal interest rate is one of the most salient features of the monetary transmission mechanism. Most researchers seek to identify positive monetary policy shocks as those innovations to money growth that exert a positive influence on output (output effect), a positive one in prices (price effect) and reduce the nominal interest rate on impact (liquidity effect). In fact, the confidence of the profession in this scheme is such that failure to produce any of those effects is taken as a puzzle that calls into question the identification procedure. Our reading of this literature is that the liquidity effect is a nominal feature that any well-defined monetary model of the business cycle must be able to produce under fairly general circumstances (see Christiano, Eichembaum and Evans (1998)).

Following the Lucas (1980) program for business cycle research, two broad classes of models aim to account for those effects emphasizing different parts of the monetary policy transmission mechanism. On the one hand, limited participation models generate a liquidity effect by allowing restrictions in the adjustment of agents' portfolios which break down the intertemporal allocation of consumption (see, Fuerst (1992) and Christiano, Eichenbaum and Evans (1997) -CEE, henceforth-). On the other hand, an alternative line of research has pointed to the role of price rigidities and capital adjustment costs as the main factors determining the behavior of nominal and real interest rates after a money supply shock (see, for instance, King and Watson (1996)). Contrary to the previous one, the liquidity effect is far from granted in this class of models since it depends on how the nominal interest rate is affected by the intertemporal allocation of wealth.

In this paper we revisit the liquidity issue within a general equilibrium model with sticky prices and capital accumulation in which money services provide utility to consumers. We show that with separable preferences, a positive money shock induces a fall in interest rates if the 
intertemporal elasticity of substitution of consumption is low enough, thus generating a large impact response of current consumption relative to future consumption. This result has been pointed out by Jeanne (1994) and CEE (1997) among others. In addition we show that a low income elasticity of money demand goes in the same direction, making the liquidity effect more likely without requiring a extremely high degree of risk aversion.

The previous results are obtained with separable preferences between consumption and leisure. Although separable preferences have been used in many monetary models, they can be hardly reconciled with the balanced growth properties unless some parametric restrictions are satisfied (see Chari, Kehoe ank McGrattan (1998)). In a model with non-separable preferences things are different since a high intertemporal substitution is needed to produce the liquidity effect. This is so because after a monetary shock consumption and leisure move in opposite directions inducing counteracting effects on the marginal utility of consumption that break down out the negative link between intertemporal substitution and the impact response of the nominal interest rate. Furthermore, if there is no capital accumulation, the model does never produce a correctly signed liquidity effect within the range of positive risk aversion values.

In order to obtain a liquidity effect we have to bring capital accumulation in the economy. But, in doing so the interest rate response to a positive monetary innovation is only negative for very high values of the elasticity of intertemporal substitution. The impact response of the nominal interest rate also depends on other parameters of the model like the degree of nominal (price) and real (capital adjustment costs) inertia. Nevertheless, these parameters are of secondary importance as compared with that of preferences as regards the ability of the model to generate the liquidity effect. Then, in this kind of models a very high intertemporal substitution is a necessary condition to generate a fall in the nominal interest rate following a monetary shock. This is most unfortunate since it generates implausibly large 
impact responses in output, employment and investment. Thus, we conclude that accounting for the observed liquidity effect still remains as an unresolved puzzle for sticky price models.

The rest of the paper is organized as follows. Section 2 presents the model and defines the equilibrium. In section 3 the model is calibrated to be compatible with a well behaved steady state. Section 4 contains the main results of the paper. Section 5 concludes with some additional remarks.

\section{The Model}

Households (indexed by $i$ ) maximise their expected lifetime utility $\widetilde{U}_{i 0}$, defined as the present discounted value of the momentary utility $U_{i t}$ conditional on the information available at $t=0$. They choose a joint plan for consumption $(C)$, leisure $(1-L)$ and end-of-period real balances $(M / P)$, where the utility of real balances stems from the transaction services provided by money:

$$
\tilde{U}_{i o}=E_{0}\left[\sum_{t=0}^{\infty} \beta^{t} U_{i t}\left(C_{i t}, \frac{M_{i t}}{P_{t}}, L_{i t}\right)\right]
$$

Each household accumulates capital and rents it to firms at the cost $Z$. The accumulation of capital is driven by,

$$
K_{i t}=I_{i t-1}+(1-\delta) K_{i t-1}
$$

where $\delta$ is the rate of depreciation, $K$ is capital and $I$ investment. Adjusting capital to its desired level is costly for the households who own it; the function of adjustment costs is chosen to produce non-zero costs in the steady state: ${ }^{1}$

$$
A C_{i t}^{K}=\frac{k}{2}\left(\frac{I_{i t}}{K_{i t}}\right)^{2} I_{i t}
$$

\footnotetext{
${ }^{1}$ These real adjustment costs are paid though the purchase of a CES basket of all the produced goods of the economy (see, Hairault and Portier (1993)).
} 
with $\phi_{K}$ as the adjustment cost scale parameter for capital.

Households decide how to allocate savings between money $(M)$, public sector debt $(B)$ and capital. They receive dividends from their share $(\omega)$ of profits $(\pi)$, nominal wage earnings $(P W)$, income derived from renting capital, interest payments from bonds and transfers $(T)$ from the government. The budget constraint faced by each household can be written as follows:

$$
\begin{aligned}
& P_{t} C_{i t}+M_{i t}+B_{i t}+P_{t} I_{i t}\left(1+\frac{\phi_{K}}{2}\left(\frac{I_{i t}}{K_{i t}}\right)^{2}\right)= \\
& P_{t} T_{i t}+P_{t} W_{t} L_{i t}+P_{t} Z_{t} K_{i t}+M_{i t-1}+r_{t-1} B_{i t-1}+P_{t} \sum_{j=1}^{J} \omega_{i j} \pi j
\end{aligned}
$$

There are $J$ firms indexed by $j$. An aggregator transforms heterogeneous goods $\left(Y_{j}\right)$ into a composite good $(Y)$, thus generating a demand schedule in terms of relative prices. More formally, the problem faced by the aggregator can be stated as follows:

$$
\operatorname{Max}_{\left\{Y_{j}\right\}} P Y-\sum_{j=1}^{J} P_{j} Y_{j} ; \quad \text { where } \quad Y=J^{1 / 1-\theta}\left[\sum_{j=1}^{J} \frac{1}{\theta} Y_{j}^{(\theta-1)}\right]^{\theta /(\theta-1)}
$$

where $\theta$ is the elasticity of substitution among the different produced goods $\left(Y_{j}\right)$ and $P_{j t}$ and $P_{t}$ are the individual and aggregate output prices respectively. Since the elasticity of substitution between the different goods is finite and higher than one, each firm has some monopoly power and cares about its own price relative to the aggregate one. The first order conditions of this problem with respect to $Y_{j}$ yield the following demand schedule:

$$
P_{j t}=P_{t}\left(\frac{J Y_{j t}}{Y_{t}}\right)^{-1 / \theta}
$$

using this result and the zero profit condition for the aggregator yields:

$$
P_{t}=\left[(1 / J) \sum_{j=1}^{J}\left(P_{j t}\right)^{1-\theta}\right]^{1 /(1-\theta)}
$$


The representative firm produces at a marginal cost that is increasing in aggregate output. With flexible prices, these functional forms imply that, in steady state, firms charge a markup of price over marginal cost equal to $\theta /(\theta-1)$. The representative firm chooses a plan for production, labour demand and capital as to maximise the expected present value of its profits: $\pi_{j 0}=E_{0} \sum_{t=0}^{\infty} \rho_{t} P_{t} \pi_{j t}$, where $\rho_{t}$ is a pricing kernel representing the marginal utility value to the representative household of an additional unit of profits accrued in period $t: \rho_{t}=\beta^{t} \Lambda_{t} \cdot{ }^{2}$ Profits and technology are given by the following expressions:

$$
\begin{gathered}
P_{t} \pi_{j t}=P_{j t} Y_{j t}-P_{t} W_{t} L_{j t}-P_{t} Z_{t} K_{j t}-P_{t} A C_{j t}^{Y} \\
Y_{j t}=A_{t} K_{j t}^{\alpha} L_{j t}^{(1-\alpha)}-\Phi
\end{gathered}
$$

where $A_{t}$ describes the economy-wide state of technology at period $t$ and $\phi$ represents a fixed cost; its existence makes it possible for a firm to earn zero profit in the long run.

The monopolistic competition environment makes it possible to incorporate sticky prices into the model. We introduce nominal price rigidity following Rotemberg (1982), by assuming that firms face convex costs of adjusting prices. Specifically, these costs are expressed as follows:

$$
A C_{j t}^{Y}=\frac{\phi_{y}}{2}\left(\frac{P_{j t}}{P_{j t-1}}-\mu\right)^{2} Y_{t}
$$

\footnotetext{
${ }^{2}$ Where $\Lambda_{t}$ represents the marginal utility of consumption.
} 
where $\phi_{y}$ measures the degree to which firms dislike to deviate in their price setting behavior from the constant inflation rate $\mu . .^{3}$

The public sector budget constraint is given by the following equation:

$$
M_{t}-M_{t-1}+\left(B_{t}-r_{t-1} B_{t-1}\right)=P_{t} T_{t}
$$

The government derives revenue from issuing money and debt, which it uses to make transfers to the households and to pay interest on outstanding debt. The monetary policy can be described by the following exogenous process for the growth of money: $M_{t} / M_{t-1}=\mu \mu_{t}$; where $\mu$ represents the steady state money growth. A shift in monetary policy takes the form of an unexpected permanent rise in money: $\mu_{t}=\mu_{t-1}^{\rho_{\mu}} \exp \left\{\varepsilon_{\mu_{t}}\right\}$, where $\varepsilon_{\mu_{t}}$ is a normally distributed i.i.d. zero mean shock with standard deviation $\sigma_{\mu}$. Finally, the fiscal policy reaction function has no stochastic component. We specify the following rule in terms of the transfers and real bonds: $P_{t} T_{t}=-\tau B_{t-1}$; where $\tau$ is a positive constant. Thus, transfers are determined to maintain dynamic stability of the model. This specification is in the spirit of Leeper (1991) and guarantees a Ricardian regime characterised by a combination of active monetary policy and passive fiscal policy.

We define a symmetric monopolistic competition equilibrium as the set of decision rules of household $i$ and firm $j$ such that:

a) The set of quantities: $Y_{j t}, C_{i t}, I_{i t}, L_{i t}, K_{i t+1}, M_{i t}, B_{i t}$ maximise the constrained present value stream of utility of the representative household and the constrained present value of profits earned by the representative firm,

b) The set of prices $\left(P_{t}, W_{t}, Z_{t}, r_{t}\right)$ clear the goods markets, the labor market and the money, bonds and capital markets.

\footnotetext{
${ }^{3}$ As noted by Woodford (1996) this model leads to a Phillips trade-off in which future inflation expectations play a crucial role in the joint dynamics of inflation and output.
} 
An extensive representation of the symmetric equilibrium is obtained from the first order conditions of both the $i_{t h}$ household and the $j_{t h}$ firm. Aggregating over $i$ and $j$ yields a set of equations which define the symmetric equilibrium of the economy (see Appendix 1 for details).

Nominal variables grow at the rate $\mu$. To solve the model we first write the equilibrium equations in terms of stationary variables $\left(\tilde{X}_{t}=X_{t} / \mu\right)$. Second, since an exact expression for the equilibrium cannot be found analytically, we approximate the solution by log-linearizing the equilibrium around the steady state. Then, following Sims (1995), we write the system of transformed equations as: $\Gamma_{0} x_{t}=\Gamma_{1} x_{t-1}+\Gamma_{2} \varepsilon_{\mu t}+\Gamma_{3} \zeta_{t}$; where $x_{t}$ is the vector of percentage deviations of endogenous variables with respect to their steady state; $\varepsilon_{\mu t}$ is the monetary policy shock, and the last term $\zeta_{t}=\left(x_{t}-E_{t-1} x_{t}\right)$ defines expectational errors. ${ }^{4}$ The parameter matrices $\Gamma_{i}$ $(\mathrm{i}=0,1,2,3)$ are non-linear transformations of the structural parameters.

\section{Specification of Preferences and Calibration}

\subsection{Preferences}

We consider three different momentary utility functions that have been extensively used in the business cycle literature and which differ from each other in the within period separability between consumption and leisure. Although separable preferences have been advocated in many monetary models with money in the utility function, such preferences can hardly be reconciled with balanced growth properties unlike non-separable preferences (King, Plosser and Rebelo (1988)). As will become clear later, the liquidity effect depends heavily on the cross derivative $U_{C L}$ once we allow for the presence of significant substitution and income effects in the labor supply. Thus, the following three alternative specifications of equation [1] have been considered:

\footnotetext{
${ }^{4}$ This solution method is based on generalized eigenvalue decomposition and it extends the one described by Blanchard and Khan (1980).
} 


$$
\begin{aligned}
& U_{i t}=\frac{1}{1-\sigma_{1}}\left[C_{i t}{ }^{2}+b\left[{ }^{2}{ }_{i t} / P_{t}\right]^{\Gamma}\right]^{\left(1-\sigma_{1}\right) / \sigma_{2}}+\kappa \frac{\left(1-L_{i t}\right)^{1+1 / \varepsilon}}{1+1 / \varepsilon} \\
& U_{i t}=\frac{1}{1-\sigma_{1}}\left[C_{i t}{ }^{2}+b\left[{ }^{M}{ }_{i t} / P_{t}\right]^{\Gamma}\right]^{a\left(1-\sigma_{1}\right) / \sigma_{2}}{ }^{\left(1-L_{i t}\right)} \psi\left(1-\sigma_{1}\right) \\
& U_{i t}=\left\{\left[C_{i t}{ }^{2}+b\left[M_{i t} / P_{t}\right]^{\Gamma}\right]^{1 / \sigma_{2}}-\psi_{0} L_{i t}^{v}\right\}^{1-\sigma_{1}}
\end{aligned}
$$

The usual restrictions imposed on the parameters ensure that the utility is concave, $C$ and $M / P$ are normal goods, and the interest elasticity of money demand is strictly negative. ${ }^{5}$ We can think of the instant utility function as depending on a composite good, which is a flexible CES aggregator of consumption and real balances. This allows us to make our exercises across alternative preferences comparable in terms of the specification of the money demand leaving the money demand properties unrestricted. In particular, the log-linear approximation of the first order conditions yields the following expression for the money demand: $m_{t}-p_{t}=\varepsilon_{c} c_{t}-\varepsilon_{r} r_{t}$, where $\varepsilon_{c}=\left(1-\sigma_{2}\right) /(1-\Gamma), \varepsilon_{r}=1 /(1-\Gamma)(1-r)$, and $r$ is the steady state nominal interest rate. Finally, notice that setting $\Gamma=\sigma_{2}$ yields a unit income elasticity of money demand.

Equation [10] represents separable preferences as the ones recently used by CEE (1997) where $\sigma_{l}>0$ characterizes risk aversion and $\varepsilon$ is the labor supply elasticity. Equation [11] is a general form of two alternative preference specifications. On the one hand, if we set $\psi=1-a$, we obtain the standard Cobb-Douglas preference specification (CD, henceforth). On the other hand, if $a=1$ we obtain the preferences used by Chari, Kehoe and McGrattan (1996)

\footnotetext{
${ }^{5}$ When $\Gamma=\sigma_{2}$ we get the usual CES aggregator. The sign of $\mathrm{U}_{\mathrm{cm}}$ equals the sign of $1-\sigma_{1}-\sigma_{2}($ where $\mathrm{m}=(\mathrm{M} / \mathrm{P}))$.
} 
from which it is easy to compute the labor supply elasticity. The third class of utility functions (expression [12]) is the one advocated by Greenwood, Hercowitz and Huffman (1988) (GHH, henceforth). These preferences have two properties that may be relevant to understanding the liquidity effect: (i) first, the elasticity of intertemporal substitution of leisure is zero; and (ii) the number of hours worked (L) is a function of the current wage, and so there is no income effect on labor supply. The elasticity of labor supply implied by these preferences is $1 / v-1$ (with $v>1$ ). Finally, the parameters $\kappa$ and $\psi_{0}$ will be chosen so that the total hours worked by agents are a given proportion of their time endowment.

\subsection{Calibration}

This section describes the benchmark values used to compute the response of the economy to monetary shocks. These parameters together with the steady state of the economy are reported in Table 1 . We set the discount parameter $\beta$ to $(0.97)^{1 / 4}$ which implies that the real interest rate is equal to 3 percent per annum. The nominal interest rates, $r$, and the inflation rate (money growth rate, $\mu$ ) were set at 1.08 and 1.05 , respectively. Our benchmark value for the risk aversion parameter $\left(\sigma_{l}\right)$ is equal to 2 . With separable and GHH preferences the elasticity of labor supply with respect to real wages was set equal to 1 . When we use non-separable preferences as in [11], the share parameter (parameter $a$ or $\psi$ ) is set as to ensure that agents work 30 percent of their time endowment. Finally, the benchmark parameters in the money demand function are $\varepsilon_{c}=1$ and $\varepsilon_{r}=0.01$. The former is essentially the long run elasticity estimate by Lucas (1988). Nevertheless, 
following King and Watson (1996) we choose a much lower value for the interest rate elasticity. ${ }^{6}$ Next, we consider the technology and capital adjustment cost parameter. The labor income share $(\alpha)$ is equal to 0.33 , and the annual depreciation rate is equal to 10 percent. The capital adjustment cost parameter, $\phi_{K}$, is set equal to 10 . This value implies that the installation of capital involves a 1.75 percent cost in terms of investment, and a capital-output ratio of 2.5 . These values are consistent with microeconometric estimates (see, for instance, Whited 1992). Nevertheless, we will also analyze the effects of changing the capital adjustment costs in terms of the liquidity effect.

We turn now to the consideration of the parameters $\theta, \Phi$ and $\phi_{y}$. The elasticity of demand is chosen $(\theta=6)$ such that the markup in a flexible price economy is 20 percent (say, 1.2). Assuming zero profits in the steady state, the previous assumption is equivalent to making the value of $\Phi / Y=(1 / \theta) A\left(k^{a} L^{(1-a)}\right)$ also equal to 20 percent. Although these values are conventional in the literature, our results do not change when a lower markup is used (say, 5 percent) as suggested by the evidence in Basu and Fernald (1997). The price adjustment cost parameter $\left(\phi_{y}\right)$ cannot be calibrated using steady state information. To choose a value we follow recent estimates of the new-keynesian Phillips trade-off by Sbordone (1998). In particular, we set $\phi_{y}=17.5^{*}(\theta-1)$, which implies that firms change prices every 9 months. ${ }^{7}$ Finally, we set $\rho_{t u}=0.5$ corresponding to the estimated value for M1 growth in the US (Cooley and Hansen (1995)).

\footnotetext{
${ }^{6}$ This low value is consistent with a low degree of substitution in money demand over the business cycle. Moreover, the empirical evidence reported by Goldfeld and Sichel (1990) is consistent with such a value. Indeed, those authors advocated a lower value for the income elasticity. We will analyze how our results depend on setting $\varepsilon_{C}$ equal to 0.2 as an alternative to unit elasticity.

${ }^{7}$ As can be seen from the previous expression, holding the time between price adjustments constant, a lower markup (higher $O$ ) implies a much higher cost of adjusting prices.
} 


\section{The Effects of Permanent Unanticipated Money Supply Shocks}

In this section we assess the role of preferences, capital accumulation and other features of our model in shaping the response of interest rates to money shocks, or the liquidity effect. We proceed step by step, first working with a version of the model with separable preferences, then introducing non-separable preferences and finally adding capital into the model. We show that for a given exogenous money growth rule the existence of a liquidity effect depends critically on the interaction of these elements with the rest of the model. With the complete model we analyze the properties of the parameterizations that generate the liquidity effect, discussing the importance of the real and nominal rigidities and of the persistence of the money growth shock for obtaining the liquidity effect.

\subsection{Economy without capital: Separable Preferences}

Let us consider a simple version of the model presented in section 2, where preferences are separable as expressed by [10], and without capital, so that the production function is defined as $Y_{j t}=A_{t} L_{j t}^{(1-\alpha)}-\Phi$. Figure $1 \mathrm{~A}$ shows that positive and persistent money shocks generate a positive and persistent response of consumption, real balances and output. Since prices are sticky, a positive nominal shock increases nominal demand and marginal costs but lowers the markup. Labor demand, output and consumption increase. Following the rise in real wages, labor supply also increases, pushing the economy closer to the competitive equilibrium. Eventually, the price level adjusts to its new level, restoring the initial reduction in the markup and returning the economy to its steady state.

Nevertheless, these real effects occur along with a positive impact on the nominal interest rate. This impact effect is characterized by two equilibrium equations representing the intertemporal allocation of consumption and the demand of money balances: ${ }^{8}$

\footnotetext{
${ }^{8}$ These are derived from expression [A1], [A3] and [A4] in Appendix 1.
} 


$$
\begin{aligned}
& U_{c, t} / P_{t}=\beta r_{t} E_{t}\left(U_{c, t+1} / P_{t+1}\right) \\
& U_{m, t} / U_{c, t}=\left(1-1 / r_{t}\right)
\end{aligned}
$$

where equation [13] represents the intertemporal Euler equation of consumption, and equation [14] determines the optimal allocation between consumption and real balances within period (i.e. it represents a money demand equation). CEE (1997) combines equation [13] with a cash-in-advance constraint obtaining an expression of the type: $C_{t} U_{c, t}=\beta r_{t} E_{t}\left\lfloor\left(C_{t+1} U_{c, t+1}\right) /\left(M_{t+1} / M_{t+2}\right)\right\rfloor$. They show that the expectational term becomes a constant (say, A) in the event that prices are set one period in advance and money growth follows an iid process. Under these assumptions, after a positive money growth shock, the only way to generate a liquidity effect is through a reduction in $C_{t} U_{c t}$. Under separability between consumption and leisure, then $r_{t}=C_{t}^{1-\sigma_{1}} / A \beta$. Thus, after an increase in the money supply that leads to a rise in $\mathrm{C}_{\mathrm{t}}$, the nominal interest rate will fall if and only if the risk aversion parameter is greater than one $\left(\sigma_{1}>1\right)$.

Unfortunately, this result cannot be so easily obtained once we relax some of the CEE's assumptions regarding the price setting and the money growth process. Nevertheless, we can still log-linearize the above expressions [13] and [14] around the steady state to obtain: ${ }^{9}$

$$
\begin{aligned}
& r_{t}-E_{t} \Delta p_{t+1}=\sigma_{1}\left(E_{t} c_{t+1}-c_{t}\right) \\
& m_{t}-p_{t}=\varepsilon_{c} c_{t}-\varepsilon_{r} r_{t}
\end{aligned}
$$

\footnotetext{
${ }^{9}$ Notice that to get this expression we are also assuming that the parameter $b$ in expressions [10]-[12] approaches to zero so real the balances disappear of [13a]. We recall that this is not a bad approximation if we calibrate the model by looking at the average velocity for M1 in US (see Chari et al. (1996) and Kim (1998)). Nevertheless, in all the simulations we eliminate this assumption.
} 
where lower case letters represent deviations from their steady state value. Solving now for the nominal interest rate in these two expressions and assuming that money demand only responds to movements in consumption $\left(\mathcal{E}_{r}=0\right):^{10}$

$$
r_{t}=\sigma_{1}\left[\frac{1}{\varepsilon_{c}} E_{t} \Delta m_{t+1}+\left(\frac{1}{\sigma_{1}}-\frac{1}{\varepsilon_{c}}\right) E_{t} \Delta p_{t+1}\right]
$$

For a given degree of money and price persistence the monetary shock generates an impact increase in money and prices that is expected to continue in the future. Under these fairly general circunstances two results follow from the above expression. The first is that, for given values of $\varepsilon_{c}$ and $\rho_{t}$, high risk aversion (i.e. a low intertemporal elasticity of substitution $\left.\left(1 / \sigma_{l}\right)\right)$ is needed for the existence of the liquidity effect.

The intuition behind this result can also be cast in terms of the impact effect on the right hand side of expression [13a], i.e. the real interest rate. After a positive money shock, consumption rises at time $t$ and rises further in $t+1$ to decline from $t+2$ onwards (see Figure 1A). Thus, the impact effect on the real interest rate is positive and it is given by $\sigma_{l}=2$ times the expected increase in consumption. This increase is further reinforced by the rise in expected inflation. A lower degree of intertemporal substitution of consumption induces a lower expected rise in consumption from $t$ to $t+1$, which will eventually become negative for very large values of $\sigma_{l}$. Thus, this produces a substantial reduction in the real interest rate (by an amount equals to $\left.\sigma_{1}\left(E_{t} c_{t+1}-c_{t}\right)\right)$ which, if strong enough, might compensate the increase in inflation

\footnotetext{
${ }^{10}$ When $\varepsilon_{\mathrm{r}}$ is different from zero we solve forward for the nominal interest rate and obtain:$$
r=f\left\{\sum_{t}^{\infty} \delta^{j}\left[\frac{1}{\varepsilon_{c} E_{t} \Delta m}{ }_{t+j+1}+\left(\frac{1}{\sigma}-\frac{1}{\sigma_{c}}\right)_{t} E_{t+j+1}^{\Delta p}\right]\right\} \text { where } \delta=\left(\frac{\kappa}{\frac{1}{\sigma}+\kappa}\right) k=\frac{\varepsilon_{r}}{\varepsilon} ; f=\left(\frac{1}{\sigma}+\kappa\right)^{-1} .
$$ 
expectations. ${ }^{11}$ The real interest rate moves to match the expected change in the marginal utility between period $t$ and $t+1$. Since consumption is the only argument of marginal utility, it is the expected change in consumption what matters for the liquidity effect. Thus, a substantial decrease in $c_{t+1}$ as compared with $c_{t}$ is needed to obtain a decline in the real interest rate; this is only possible if households are willing to smooth consumption over time, i.e. if $\left(1 / \sigma_{l}\right)$ is low enough.

The second result is that for sufficiently low money demand elasticity with respect to consumption $\left(\varepsilon_{\mathrm{c}}\right)$, the liquidity effect may also be obtained without requiring a high value for risk aversion. In our model, money is introduced as an argument in the utility function and the short run consumption elasticity is left free so that a low value of $\varepsilon_{c}$ favors an impact fall in the nominal rate. The lower the income elasticity of money demand the smaller the substitution away from bonds and thus the more likely the impact fall in the interest rate following the initial increase in the supply of real money balances.

To put some numbers to these results, we simulate in Figure 1B the impact effect on the nominal interest rate and real balances of a money growth shock under different values of the risk aversion parameter. This Figure confirms the previous surmise. Thus, in sticky price models if preferences are separable, the higher the risk aversion the more likely is the liquidity effect. Notice that the existence of price and money growth persistence implies an implausibly large degree of risk aversion in order to generate the liquidity effect. When the income elasticity of real balances is less than one a lower value of the risk aversion will generate that effect.

\footnotetext{
${ }^{11}$ In a cash-in-advance economy without capital Jeanne (1994) also gets this result.
} 


\subsection{Economy without capital: Non-Separable Preferences}

When preferences are non-separable, things are different. In particular, expression [15] no longer represents the interest rate response since the intertemporal allocation of consumption depends on other features of the model. Figure $2 \mathrm{~A}$ shows the response of the main variables in the model to a persistent money shock. The results correspond both to Cobb-Douglas preferences and to GHH preferences. At first glance, the impulse response functions look very similar in this economy as compared with those in a world with separable preferences (i.e. those depicted in Figure 1A): a positive monetary shock increases output, consumption and real balances, while the nominal interest rate still increases on impact. Nevertheless, a closer look at the results shows an interesting departure from the general proposition enunciated above. As the sensitivity analysis in Figure 2B makes clear, a higher risk aversion is no longer a necessary condition for the existence of the liquidity effect. Indeed the opposite is true.

To give some intuition for this latter result, we consider the non-separable preferences given by expression [11], when $a=1$. Proceeding at in the previous section, the log-linear equation for the intertemporal consumption allocation [13] takes now the following form:

$$
r_{t}-E_{t} \Delta p_{t+1}=\left(\frac{\bar{L} \psi}{1-\bar{L}}\right)\left(1-\sigma_{1}\right)\left(E_{t} \ell_{t+1}-\ell_{t}\right)+\sigma_{1}\left(E_{t} c_{t+1}-c_{t}\right)
$$

This expression states that the real interest rate moves as to ensure the equalization of the marginal utility of consumption between $t$ and $t+1$, but now the ratio of marginal utilities not only depends on the expected change in consumption but also on the expected response of labor supply. As the elasticity of intertemporal substitution, $\left(1 / \sigma_{l}\right)$, falls both $E_{t} \Delta c_{t+1}$ and $E_{t} \Delta \ell_{t+1}$ become smaller and eventually negative, exerting opposite effects upon the ratio of marginal utilities; the leisure effect dominates making the liquidity effect less rather than more likely for given inflation expectations. 
An additional result is that in this case the liquidity effect is never obtained for positive values of $\sigma_{l}$. This result also relies heavily on the fact that in a model without capital consumption is proportional to labor (i.e. $c_{t} \approx \alpha \ell_{t}$ ). Thus, for the benchmark values of the parameters the expected increase in consumption and leisure roughly compensate each other in expression [13b] leaving the nominal interest rate almost unchanged, for a given expected inflation, as we move towards higher values of the risk aversion.

As noted in section 3, the CD preferences impose strong income and substitution effects on leisure after a positive money shocks. Thus, we now analyze how allowing for a zero intertemporal substitution effect on leisure and a zero income effect on labor supply affect our previous result. We use the GHH preferences that imply the following (log-linear) expression for the intertermporal consumption allocation:

$$
(1-\eta / v)\left(r_{t}-E_{t} \Delta p_{t+1}\right)=\sigma_{1}\left[\left(E_{t} c_{t+1}-c_{t}\right)-\eta\left(E_{t} \ell_{t+1}-\ell_{t}\right)\right]
$$

where the steady state solution imposes $\eta=(1-\alpha) /(\mathrm{c} / \mathrm{y}) .{ }^{12}$ Whith these preferences households smooth $\left(c_{t}-\eta \ell_{t}\right)$ over time instead of $c_{t}$ and, unlike with CD preferences, the parameter $\eta$ is independent of the intertemporal substitution. The absence of an income effect on the labor supply makes the movements in consumption and leisure roughly proportional and such proportion is independent of the degree of intertemporal substitution. Moreover, increases in the risk aversion $\left(\sigma_{l}\right)$ affect the nominal interest rate more significantly than in the case of $\mathrm{CD}$ preferences but always in the opposite direction that required for a liquidity effect.

Since this is a most unfortunate feature of the model we may ask at this point what does it take to obtain a proper liquidity effect in a sticky price model with non-separable preferences.

\footnotetext{
${ }^{12}$ In general this parameter is close to one in market economies.
} 
What we need is a mechanism that drives the response of labor supply and consumption significantly apart so that the real interest rate could fall substantially on impact.

\subsection{Economy with capital: Non-separable Preferences}

Capital accumulation is a key feature of the model that is expected to have a major effect on the way some endogenous variables respond to a monetary shock. In particular, current consumption can be made less responsive to the money shock for a given output response, since households devote part of their income to invest in capital goods (in addition to bonds and real balances). We will show that in order to generate the liquidity effect the mere presence of capital is not enough, what is needed is strong incentive to accumulate it. This can be obtained in the model previously discussed by means of high degree of intertemporal substitution (say, $1 / \sigma_{l}$ ) and low adjustment costs of capital $\left(\phi_{k}\right)$. The reason why we need a high intertemporal substitution stems from the fact that with low intertemporal substitution the response of consumption after a persistent money shock is similar to that in output so that the pattern of impulse-responses resemble very much that of an economy without capital. ${ }^{13}$

The impulse responses in Figure 3A of an economy with capital accumulation show that the previous surmise is correct. Still, in the case of high risk aversion values there are not incentives to save and accumulate capital, and therefore the allocation of real balances and consumption has not undergone a significant change with respect to the model without capital. Thus the money market equilibrium generates the same path in terms of interest rates: an increase on impact followed by a smooth decrease over time. Nevertheless, the money shock simulation when $\sigma_{l}$ is low generates a large substitution effect that is reflected in a huge output and labor responses on impact but only a small change in consumption. For $\sigma_{l}=0.75$ the interest

\footnotetext{
${ }^{13}$ A similar reasoning applies to a high value of the capital adjustment costs $\left(\phi_{k}\right)$.
} 
rate response generates a liquidity effect. We can explain the impact response of interest rates in terms of the expression [13b]: if the risk aversion parameter is less than one, then there is a large expected fall in labor after the first period that moves the current interest rates down. ${ }^{14}$

The impulse responses in Figure 3A also highlight the role of capital in this model. Since $1 / \sigma_{1}(1 / 0.75)$ is large, consumers have the incentive to postpone consumption which, unlike the model without capital, does not necessarily implies postponing production (and so employment) too. On the contrary, as the real rate falls the initial jump in the expected shadow price of capital leads to a sharp increase in the demand for investment. Since, given the existence of sticky prices, output is demand determined the increase in investment translates into output so increasing labor demand alongside. ${ }^{15}$ As can be seen in expression [13b], now the sharp expected reduction in labor $\left(E_{t} \Delta \ell_{t+1}\right)$ more than compensates the expected consumption increase $\left(E_{t} \Delta c_{t+1}\right)$ to produce a strong fall in the real interest rate. Why do households postpone consumption and work harder today despite the fact that the real rate has fallen? The reason is that there is a new asset, capital, which makes very profitable any additional amount of resources devoted to accumulate it. As $1 / \sigma_{1}$ gets smaller all these effects become smaller too and the economy resembles very much the one without capital in which consumption and labor balance each other its effect on the marginal utility of the household so leaving no room for movements in the real interest rate.

\footnotetext{
${ }^{14}$ In Appendix 2 we show the implications of such a risk aversion parameter in terms of the labor supply elasticity.

${ }^{15}$ Notice that the additional output demand in period $t$ must be entirely met by a rise in employment since $K_{t}$ is predetermined.
} 
To sum up, when preferences are non-separable and there is capital accumulation the liquidity effect is more likely the smaller the risk aversion parameter, just the opposite of what happens in an economy with separable preferences. Nevertheless the range of values for which such an effect exists is very small and is always for risk aversion values lower than one (see Figure 3B). That generates implausibly large movements in output and labor whereas consumption movements remain very low after a monetary shock.

To get a more complete picture of the features shaping the initial response of the nominal interest rate in this model, we check the robustness of our results with respect to the remaining parameters of the model. Figure 4 depicts the results of sensitivity analyses with regard to nominal and real rigidities as well as to the money shock persistence. Within the low risk aversion region (dotted line) the liquidity effect is more likely the lower the adjustment cost of capital, the lower persistence of the money growth shock and the higher the price stickiness. The cost of adjusting capital is borne by households and the lower this cost the higher the incentive to accumulate capital, leading to the stronger output and employment responses needed to guarantee the liquidity effect. The impact response of the nominal interest rate is always higher, and that of real balances lower, the higher the value of $\rho_{\mu}$. Similarly, as expected, real balances rise and the interest rate falls more, the higher the value of $\phi_{Y}$, i.e. the liquidity effect is more likely the higher the degree of price inertia. Within the region of higher risk aversion (continuous), the sensitivity of the interest rates and real balances to this parameter is much lower. Therefore, under non-separability and capital accumulation the risk aversion parameter is the crucial one, as compared with those reflecting the intensity of price inertia and capital adjustment costs, in shaping interest rate movements. 


\section{Conclusions}

Although neither the output nor the price effects of a monetary expansion need to be preceded by a fall in the nominal interest rate, the liquidity effect is viewed by many economists as one of the well established empirical facts in monetary economics. General equilibrium models aimed at representing such mechanism face the challenge of reproducing the liquidity effect along with other business cycle features of market economies. In this paper we have discussed under what conditions a general equilibrium model with costs of adjusting prices and capital is capable of generating a downwards movement of the nominal rate following a positive monetary innovation.

In a world without capital and separable preferences, the logic of the intertemporal allocation of wealth leads to the following result: it takes a low elasticity of intertemporal substitution for the nominal rate to fall on impact. We show that it is also possible to get the same result by reducing the income elasticity of money demand over the business cycle. This is so because the marginal utility of consumption is just driven by the dynamics of consumption. When preferences are not separable the previous result does not apply. Now, the impact response of nominal interest rate is not sensitive to changes in the intertemporal substitution. The reason is also straightforward: now consumption and labor supply movements balance each other its effect on the marginal utility of the household so leaving no room for movements in the real interest rate.

In an economy with non-separable preferences and capital accumulation the liquidity effect is not achieved unless the intertemporal substitution is very high and the capital adjustment costs are not high. In such a case, this intertemporal substitution effects leads households to postpone consumption investing in capital and so increasing current output and labor demand by 
an amount large enough to reduce the real interest rate by more than the expected increase in prices.

The logic of this result can be analyzed in the light of the monetary transmission mechanism of the simplest limited participation model. In this kind of models, restrictions on the adjustment of consumer's portfolios make it possible that the additional liquidity of the system is not necessarily devoted to consumption. The additional savings must be devoted to increase the demand of productive factors, which firms are willing to do if the interest rate falls. In sticky price models where the marginal utility of consumption depends upon consumption and leisure we can get a similar result imposing a strong bias towards the intertemporal substitution and low adjustment costs of capital. Nevertheless, in this latter model this comes at the cost of generating implausibly large impact responses in output, employment and investment.

Finally, the impact response of the nominal interest rate also depends on other parameters of the model like the degree of nominal (price) and real (capital adjustment costs) inertia. Nevertheless, these parameters are of secondary importance as compared with that of preferences as regards the ability of the model to generate the liquidity effect. Thus, we conclude that accounting for the observed liquidity effect still remains as an unresolved puzzle for sticky price models of the monetary transmission mechanism. 


\section{Appendix 1: An extensive representation of the symmetric monopolistic competition equilibrium}

The household's choice is given by:

$$
\begin{aligned}
& \frac{\partial U}{\partial C_{\mathrm{t}}}=\Lambda_{\mathrm{t}} \\
& \frac{\partial U}{\partial \mathrm{L}_{\mathrm{t}}}=-\Lambda_{\mathrm{t}} \mathrm{P}_{\mathrm{t}} \mathrm{W}_{\mathrm{t}} \\
& \Lambda_{\mathrm{t}}=\beta \mathrm{E}_{\mathrm{t}} \mathrm{r}_{\mathrm{t}+1} \Lambda_{\mathrm{t}} \\
& \frac{\partial U}{\partial \mathrm{M}_{\mathrm{t}}}=\Lambda_{\mathrm{t}}-\beta \mathrm{E}_{\mathrm{t}} \Lambda_{\mathrm{t}+1}
\end{aligned}
$$

Optimal capital accumulation is derived from the first order conditions of households with respect to investment and capital:

$$
\begin{gathered}
\Lambda_{\mathrm{t}}\left[\mathrm{P}_{\mathrm{t}} \mathrm{Z}_{\mathrm{t}}+\mathrm{P}_{\mathrm{t}} \phi_{\mathrm{k}}\left[\frac{\mathrm{I}_{\mathrm{t}}}{\mathrm{K}_{\mathrm{t}}}\right]^{3}\right]-\mathrm{q}_{\mathrm{t}}+\beta(1-\delta) \mathrm{E}_{\mathrm{t}} \mathrm{q}_{\mathrm{t}+1}=0 \\
\Lambda_{\mathrm{t}} \mathrm{P}_{\mathrm{t}}\left[1+\frac{3 \phi_{\mathrm{k}}}{2}\left[\frac{\mathrm{I}_{\mathrm{t}}}{\mathrm{K}_{\mathrm{t}}}\right]^{2}\right]=\beta \mathrm{E}_{\mathrm{t}} \mathrm{q}_{\mathrm{t}+1}
\end{gathered}
$$

The first order conditions of the firm with respect to the employment and capital yields the following relationships:

$$
\begin{aligned}
& \mathrm{W}_{\mathrm{t}}=(1-\alpha)\left[\frac{\mathrm{Y}_{\mathrm{t}}-\Phi}{\mathrm{L}_{\mathrm{t}}}\right]\left[1-\left(1 / \mathrm{e}_{\mathrm{Yt}}\right)\right] \\
& \mathrm{Z}_{\mathrm{t}}=\alpha\left[\frac{\mathrm{Y}_{\mathrm{t}}-\Phi}{\mathrm{K}_{\mathrm{t}}}\right]\left[1-\left(1 / \mathrm{e}_{\mathrm{yt}}\right)\right]
\end{aligned}
$$

where $e_{Y t}$ takes the following expression:

$$
\mathrm{e}_{\mathrm{Yt}}=\theta\left\{1-\phi_{\mathrm{Y}}\left(\frac{\mathrm{P}_{\mathrm{t}}}{\mathrm{P}_{\mathrm{t}-1}}\right)\left[\frac{\mathrm{P}_{\mathrm{t}}}{\mathrm{P}_{\mathrm{t}-1}}-\mu\right]+\phi_{\mathrm{Y}} \mathrm{E}_{\mathrm{t}}\left[\frac{\rho_{\mathrm{t}+1}}{\rho_{\mathrm{t}}}\left(\frac{\mathrm{P}_{\mathrm{t}+1}}{\mathrm{P}_{\mathrm{t}}}\right)^{2} \frac{\mathrm{Y}_{\mathrm{t}+1}}{\mathrm{Y}_{\mathrm{t}}}\left(\frac{\mathrm{P}_{\mathrm{t}+1}}{\mathrm{P}_{\mathrm{t}}}\right)\right]\right\}^{-1}
$$

The model also assumes that every agent has access to a complete and competitive market for contingent claims. This is equivalent to say that firms maximize their market value. In such a situation, there is a unique real discount factor satisfying:

$$
\left\{\frac{\rho_{\mathrm{t}+1}}{\rho_{\mathrm{t}}}\right\}=\beta\left\{\frac{\Lambda_{\mathrm{t}+1}}{\Lambda_{\mathrm{t}}}\right\}
$$

Finally, four constraints guarantee that markets clear. These are given by the production function, capital accumulation, the government budget constraint and the economy wide constraint.

$$
\begin{gathered}
\mathrm{M}_{\mathrm{t}}-\mathrm{M}_{\mathrm{t}-1}+\left(\mathrm{B}_{\mathrm{t}}-\mathrm{r}_{\mathrm{t}-1} \mathrm{~B}_{\mathrm{t}-1}\right)=\mathrm{P}_{\mathrm{t}} \mathrm{T}_{\mathrm{t}} \\
\mathrm{K}_{\mathrm{t}}=\mathrm{I}_{\mathrm{t}-1}+(1-\delta) \mathrm{K}_{\mathrm{t}-1} \\
\mathrm{Y}_{\mathrm{t}}=\mathrm{A}_{\mathrm{t}} \mathrm{L}_{\mathrm{t}}^{1-\alpha} \mathrm{K}_{\mathrm{t}}^{\alpha}-\Phi
\end{gathered}
$$


to obtain the economy wide constraint we proceed as follows. Using the definition of profits

$$
\pi_{\mathrm{t}}=\mathrm{Y}_{\mathrm{t}}-\mathrm{W}_{\mathrm{t}} \mathrm{L}_{\mathrm{t}}-\mathrm{Z}_{\mathrm{t}} \mathrm{K}_{\mathrm{t}}-\mathrm{AC}_{\mathrm{t}}^{\mathrm{Y}}
$$

and imposing the government budget constraint in the household budget constraint yields:

$$
\mathrm{C}_{\mathrm{t}}+\mathrm{I}_{\mathrm{t}}\left(1+\frac{\phi_{\mathrm{K}}}{2}\left(\frac{\mathrm{I}_{\mathrm{t}}}{\mathrm{K}_{\mathrm{t}}}\right)^{2}\right)=\mathrm{Y}_{\mathrm{t}}-\mathrm{AC}_{\mathrm{t}}^{\mathrm{Y}}
$$

Price adjustment costs take the following quadratic expression:

$$
\mathrm{AC}_{\mathrm{t}}^{\mathrm{Y}}=\frac{\phi_{\mathrm{Y}}}{2}\left(\frac{\mathrm{P}_{\mathrm{t}}}{\mathrm{P}_{\mathrm{t}-1}}\right)^{2} \mathrm{Y}_{\mathrm{t}}
$$

We specify the following fiscal policy in terms of the transfers:

$$
\mathrm{P}_{\mathrm{t}} \mathrm{T}_{\mathrm{t}}=-\tau \mathrm{B}_{\mathrm{t}-1}
$$

Where $\tau$ is a positive constant. Thus, transfers are determined to maintain dynamic stability of the model. The equation for the monetary policy completes the system of 17 dynamic equations with 17 endogenous variables: 7 prices $\left(P_{t}, W_{t}, Z_{t}, \Lambda_{t}, \rho_{t}, q_{t}, r_{t}\right), 5$ quantities $\left(Y_{t}, C_{t}, I_{t}, L_{t}, T_{t}\right), 3$ stocks $\left(M_{t}, B_{t}, K_{t}\right)$, the mark-up $\left(\left(1-\left(1 / e_{Y t}\right)\right)^{-1}\right)$ and the price adjustment costs $\left(A C_{t}^{Y}\right)$. 


\section{Appendix 2: Liquidity Effect and Labor Supply Elasticity}

To give some additional insights as to why do we need an economy with low risk aversion and capital we performed the following exercise. The Panel A of Table A2 presents how changes in the risk aversion translate into: (i) alternative intertemporal (Frisch) labor supply elasticities; and (ii) different impact effects on nominal interest rates $\left(r_{t}\right)$ and labor $\left(\mathrm{L}_{t}\right)$. In the economy without capital, changes in the intertemporal elasticity of substitution leaves practically unchanged the initial impact effect on $L_{t}$, and thus on $r_{t}$. The same exercise in an economy with capital reveals two interesting features: first there is a dramatic increase in the output and employment response; second, and most important, this effect is five times as large when $\sigma_{l}$ equals 0.5 as compared with $\sigma_{l}=1.0$. In the economy without capital there is no evidence of liquidity effect. This result is robust to alternative Frisch labor supply elasticities and steady state hours worked. In an economy with capital, low values of risk aversion still translate into high enough Frisch labor supply elasticities. Both circumstances imply that very small changes in the real wages are associated with very important impact effects on labor. ${ }^{16}$ Since with these preferences both intertemporal substitution and income effects play a very important role in tracing out the impact response of labor, the result translate into a huge expected reduction in the marginal utility of consumption and so in an important liquidity effect.

\section{TABLE A2. LIQUIDITY EFFECT AND LABOR SUPPLY ELASTICITY} (CD PREFERENCES)

ECONOMY WITHOUT CAPITAL

\begin{tabular}{lcccccc}
\hline \multicolumn{1}{c}{$\sigma_{1}$} & 0.5 & 0.65 & 0.70 & 0.75 & 0.80 & 1.00 \\
\hline $\mathbf{A )} \mathbf{L}=\mathbf{0 . 3}(\mathbf{a}=\mathbf{0 . 4 0})$ & & & & & & \\
Frisch Labor Supply & - & 3.09 & 2.94 & 2.80 & 2.68 & 2.33 \\
r Impact Effect & - & 0.47 & 0.47 & 0.47 & 0.47 & 0.47 \\
L Impact Effect & - & 0.92 & 0.92 & 0.92 & 0.92 & 0.92 \\
B) $\mathbf{L = 0 . 2}(\mathbf{a}=\mathbf{0 . 2 7})$ & & & & & & \\
Frisch Labor Supply & 6.90 & 5.56 & 5.24 & 4.97 & 4.72 & 4.00 \\
r Impact Effect & 0.47 & 0.47 & 0.47 & 0.47 & 0.47 & 0.47 \\
L Impact Effect & 0.94 & 0.94 & 0.94 & 0.94 & 0.94 & 0.94 \\
\hline
\end{tabular}

\section{ECONOMY WITH CAPITAL}

\begin{tabular}{|c|c|c|c|c|c|c|}
\hline$\sigma_{1}$ & 0.5 & 0.65 & 0.70 & 0.75 & 0.80 & 1.00 \\
\hline \multicolumn{7}{|l|}{ A) $L=0.3(a=0.33)$} \\
\hline Frisch Labor Supply & - & 3.18 & 3.00 & 2.85 & 2.72 & 2.33 \\
\hline r Impact Effect & - & -2.05 & -0.67 & -0.09 & 0.18 & 0.47 \\
\hline L Impact Effect & - & 20.65 & 14.60 & 11.17 & 9.05 & 5.34 \\
\hline \multicolumn{7}{|l|}{ B) $\mathrm{L}=0.2(\mathrm{a}=0.22)$} \\
\hline Frisch Labor Supply & 7.12 & 5.68 & 5.34 & 5.00 & 4.78 & 4.00 \\
\hline r Impact Effect & -2.27 & -0.03 & 0.16 & 0.28 & 0.35 & 0.47 \\
\hline Limpact Effect & 23.07 & 11.63 & 9.95 & 8.71 & 7.78 & 5.55 \\
\hline
\end{tabular}

Note: The impact effects correspond to expansionary money shocks. The rest of the parameters are taken from Table 1 . The letters $\mathrm{r}, \mathrm{L}$ corresponds to nominal interest rate and labor, respectively.

\footnotetext{
${ }^{16}$ In the economy with capital under $\sigma_{1}=0.75$ and $L=0.2$ the impact response of real wages is 0.35 .
} 


\section{References}

Basu, S. and J.G. Fernald (1997): "Returns to Scale in US Production: Estimates and Implications", Journal of Political Economy, 105, 249-283.

Blanchard O.J. and C.M. Khan (1980): "The solution of Linear Difference Models under Rational Expectations", Econometrica 48, 1305-13.

Chari, V.V., P.J. Kehoe and E.R. McGrattan (1996): "Sticky Price Models of the Business Cycle: Can the Contract Multiplier Solve the Persistence Problem?”, NBER WP 5809.

Chari, V.V., P.J. Kehoe and E.R. McGrattan (1998): "Monetary shocks ad real interest rates in sticky price models of international business cycle”, Federal Reserve Bank of Minneapolis, Research Dpt. Staff Report 233.

Christiano, L., M. Eichenbaum and C. Evans (1997): "Sticky Price and Limited Participation Models: A Comparison", European Economic Review, 41 (6), 1201-1249.

Christiano, L., M. Eichenbaum and C. Evans (1998): "Monetary Policy Shocks: What Have we Learned and to What End?" NBER WP 6400.

Cooley, T. and G. Hansen (1995): "Money and the Business Cycle", in T. Cooley (editor) Frontiers of Business Cycle Research, Princeton Universtity Press, Princeton, New Yersey, $175-216$

Fuerst,T.(1992):"Liquidity, Loanable Funds and Real Activity",Journal of Monetary Economics 29, 3-24.

Hairault, J. and F. Portier (1993): "Money, New-Keynesian Macroeconomics and the Business Cycle", European Economic Review 37, 1533-1568.

Jeanne, O, (1994): "Nominal Rigidities and the Liquidity Effect", mimeo ENCP-CERAS.

Goldfeld, S. and D. Sichel (1990): "The Demand for Money", in B. Friedman and F. Hahn (eds.), Handbook of Monetary Economics, vol. I Amsterdam: North Holland, 299-356. 
Greenwood, J.; Zvi Hercowitz and G. Huffman (1988): "Investment, Capacity of Utilization and the Real Business Cycle", American Economic Review, 78, 402-417.

Kim, J. (1998): "Monetary Policy in a Stochastic Equilibrium Model with Real and Nominal Rigidities". Divisions of Research \& Statistics and Monetary Affairs. Federal Reserve Board, forthcoming Journal of Monetary Economics

King, R.G.; Plosser, G. and S. Rebelo (1988): "Production, Growth and Business Cycles I: The Basic Neoclassical Model", Journal of Monetary Economics, 21, 195-232.

King, G.R. and Watson, M. (1996): "Money, Prices, Interest Rates and the Business Cycle”, Review of Economics and Statistics, 78, 35-53.

Leeper, E. (1991): " Equilibria under "Active" and "Passive" Monetary and Fiscal Policies", Journal of Monetary Economics 27, 129-147.

Lucas, R.E. (1980): "Methods and Problems in Business Cycle Theory", Journal of Money Credit and Banking, 12 (4), 696-715.

Lucas, R.E: (1988):"Money Demand in the United States: A Quantitative Review", Carnegie Rochester Conference Series on Public Policy, 29, 137-167.

Rotemberg, J.(1982): "Sticky Prices in the United States", JPE, 90, 1187-1211.

Sbordone, A.(1998):"Price and Unit Labor Costs: A New Test of Price Stickiness",IIES.WP 653.

Sims, C. (1995): "Solving Linear Rational Expectations Models", mimeo, Yale University.

Whited, T. (1992): "Debt, Liquidity Constraints and Corporate Investment: Evidence from Panel Data", The Journal of Finance 47, 1425-60.

Woodford, M. (1996): "Control of the Public Debt: A Requirement for Price Stability", NBER WP 5684 
FIGURE 1

PANEL A: IMPULSE RESPONSE TO A PERSISTENT MONEY GROWTH SHOCK SEPARABLE PREFERENCES WITHOUT CAPITAL
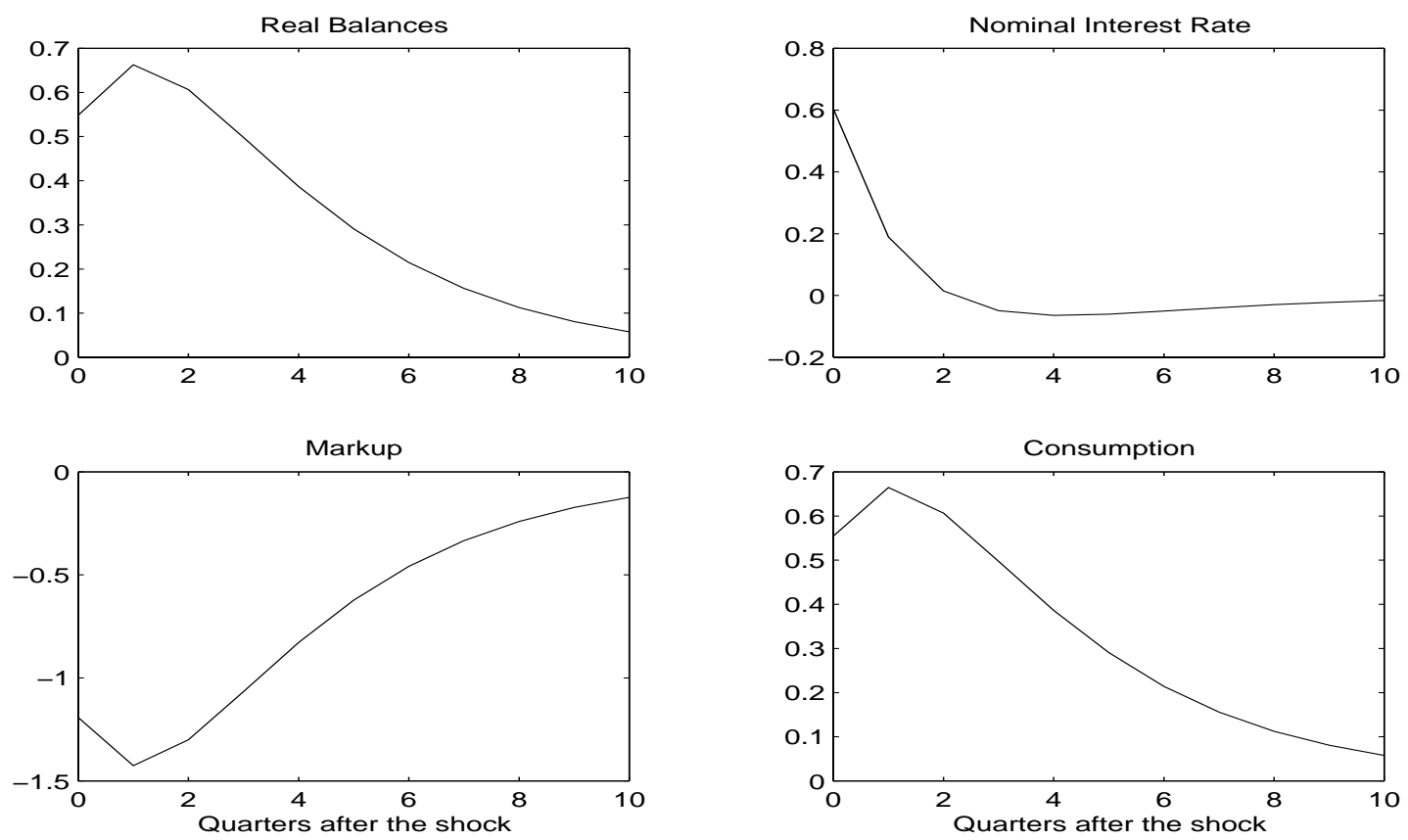

Note: Parameter Values: $\sigma_{1}=2, \varepsilon=1, \phi_{\mathrm{Y}}=85, \rho_{\mathrm{N}}=0.5$ and $\varepsilon_{\mathrm{c}}=1$.

PANEL B: ROBUSTNESS TO CHANGES IN THE RISK AVERSION
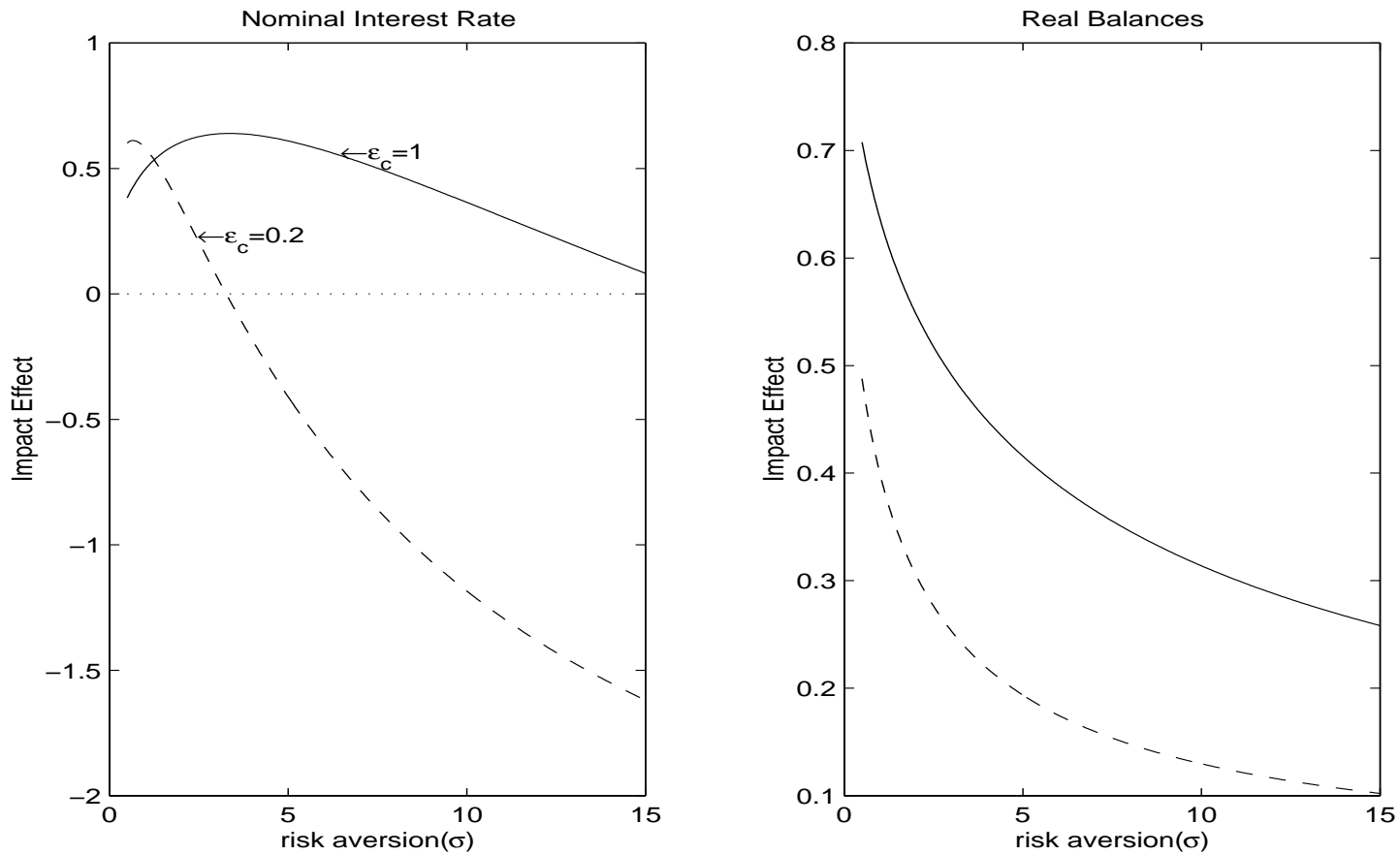

Note: Parameter Values: $\varepsilon=1, \phi_{Y}=85$ and $p_{\mu}=0.5$. 


\section{FIGURE 2}

PANEL A: IMPULSE RESPONSE TO A PERSISTENT MONEY GROWTH SHOCK NON-SEPARABLE PREFERENCES (CD-GHH) WITHOUT CAPITAL
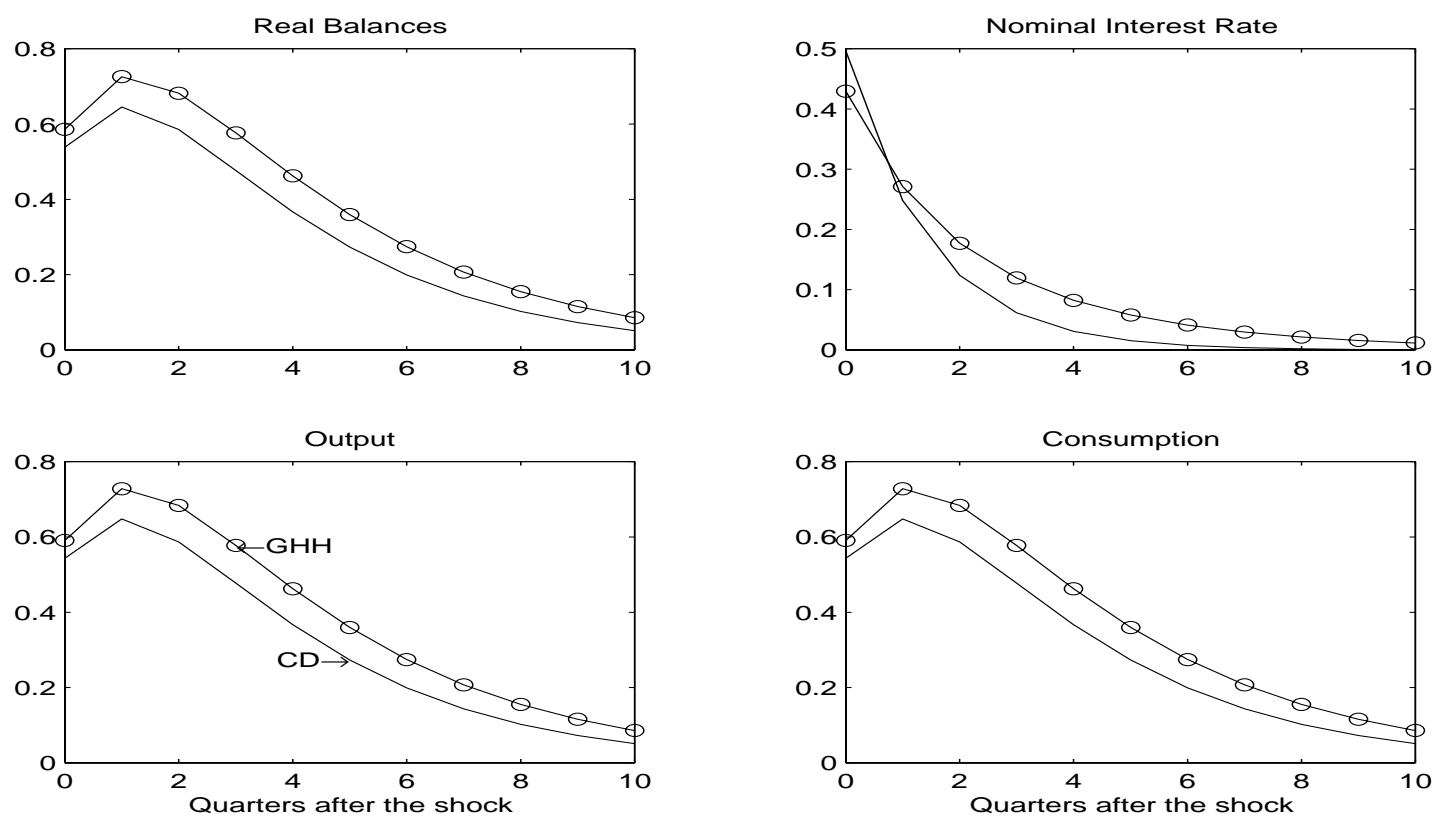

Note: Parameter Values: $\sigma_{1}=2, \psi=1-\mathrm{a}=0.60, \mathrm{v}=2, \phi_{\mathrm{Y}}=85, \rho_{\mathrm{N}}=0.5$ and $\varepsilon_{\mathrm{c}}=1$.

PANEL B: ROBUSTNESS TO CHANGES IN THE RISK AVERSION
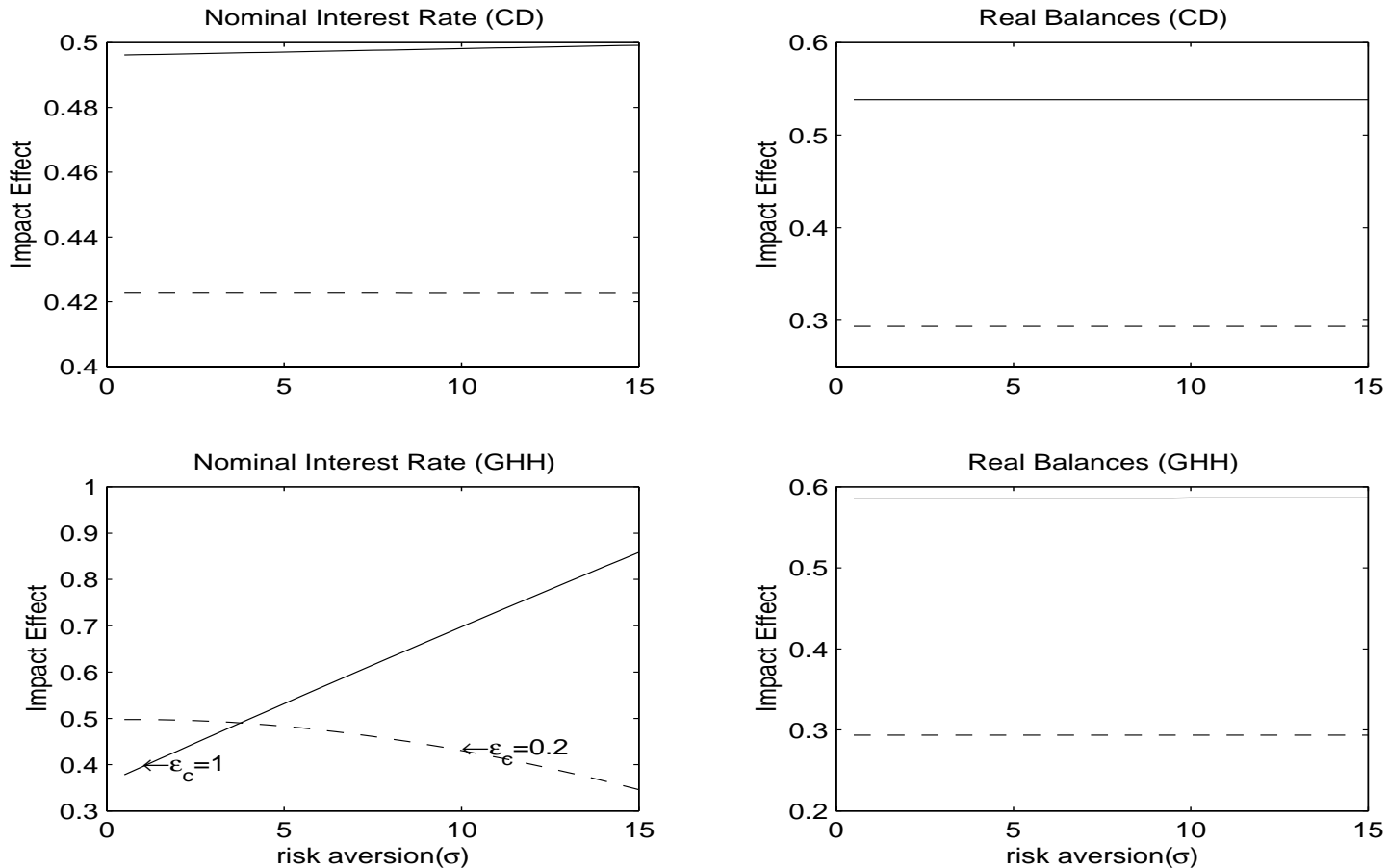

Note: Parameter Values: $\psi=1-\mathrm{a}=0.6, \mathrm{v}=2, \phi_{\mathrm{Y}}=85$ and $p_{\mathrm{N}}=0.5$. 


\section{FIGURE 3}

PANEL A: IMPULSE RESPONSE TO A PERSISTENT MONEY GROWTH SHOCK NON-SEPARABLE PREFERENCES (CD) WITH CAPITAL
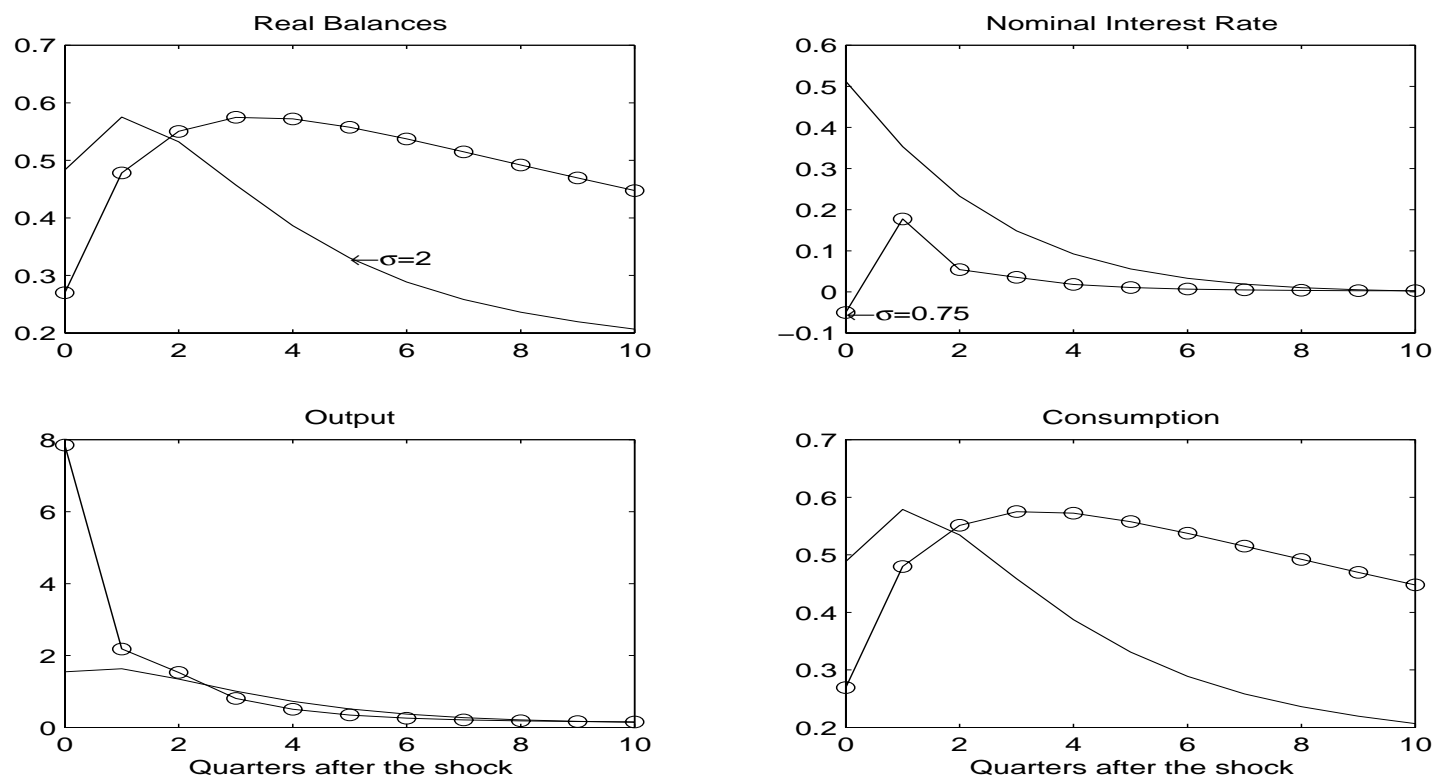

Note: Parameter Values: $\sigma_{1}=2, \psi=1-\mathrm{a}=0.67, \phi_{\mathrm{Y}}=85, \phi_{\mathrm{k}}=10, \mathrm{p}_{\mathrm{\mu}}=0.5$ and $\varepsilon_{\mathrm{c}}=1$.

PANEL B: ROBUSTNESS TO CHANGES IN THE RISK AVERSION COMPARING CD WITH GHH PREFERENCES
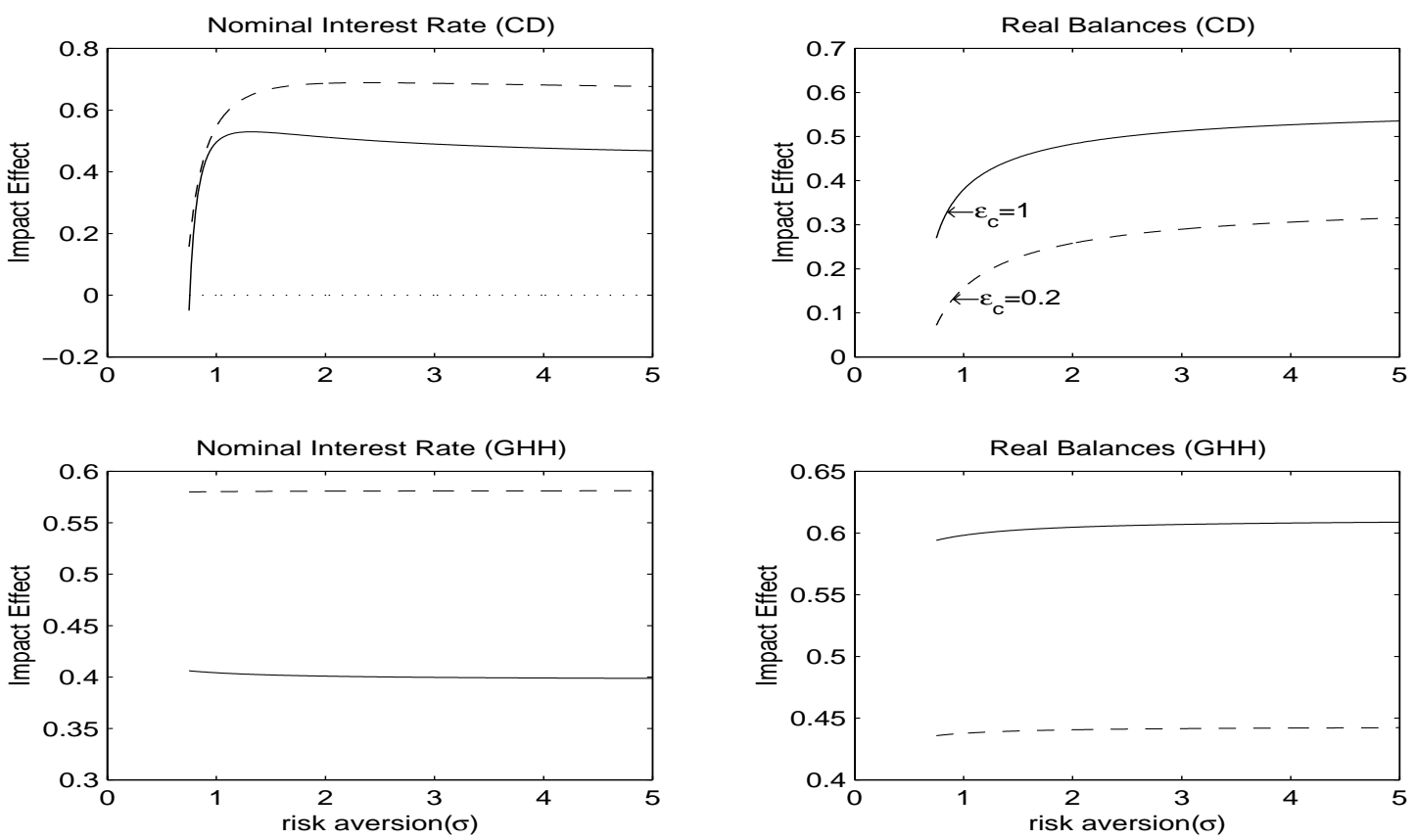

Note: Parameter Values: $\psi=1-\mathrm{a}=0.67, \mathrm{v}=2, \phi_{\mathrm{Y}}=85, \phi_{\mathrm{k}}=10$ and $\mathrm{p}_{\mathrm{N}}=0.5$. 


\section{FIGURE 4}

\section{SENSITIVITY ANALYSIS \\ NON-SEPARABLE PREFERENCES (CD) WITH CAPITAL}
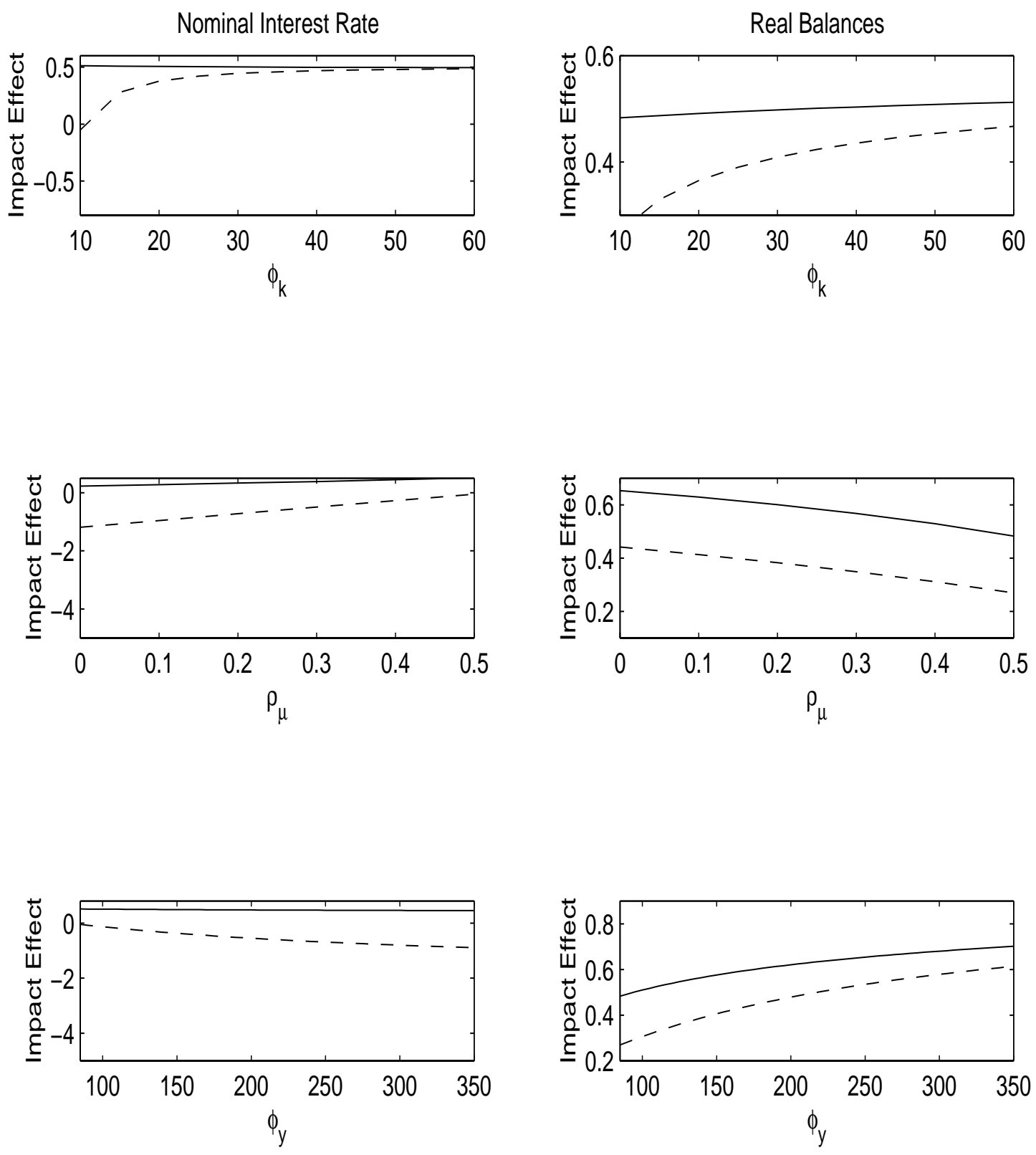

Notes:

(i) Continuous line $\sigma_{1}=2$ and the dotted line $\sigma_{1}=0.75$.

(ii) In the first panel (Robustness to $\phi_{\mathrm{k}}$ ) we set $\psi=1-\mathrm{a}=0.6, \phi_{\mathrm{y}}=85$ and $\varepsilon_{\mathrm{c}}=1, p_{\mathrm{\mu}}=0.5$.

(iii) In the second panel (Robustness to $p_{\mu}$ ) we set $\psi=1-a=0.6, \phi_{\mathrm{y}}=85, \phi_{\mathrm{k}}=10$ and $\varepsilon_{\mathrm{c}}=1$.

(iv) In the third panel (Robustness to $\phi_{\mathrm{y}}$ ) we set $\Psi=1-\mathrm{a}=0.6, \phi_{\mathrm{k}}=10, \varepsilon_{\mathrm{c}}=1$ and $p_{\mathrm{\mu}}=0.5$. 
TABLE 1

A. BASELINE VALUES FOR CALIBRATION PARAMETERS

Description

Parameter

Value

Discount Factor

$\beta$

$(0.97)^{1 / 4}$

Preferences

a) Separables

Labor supplv elasticity

Risk aversion

b) Non-Separables (Cobb Douglas(CD))

Risk aversion

c) Non-Separables (Greenwood-HercowitzHuffman (GHH))

Labor supply elasticity

$\begin{array}{cc}\mathrm{E} & 1.00 \\ \sigma_{1} & 2.00 \\ \sigma_{1} & 2.00\end{array}$

Money Demand Properties

Consumption elasticity $\left(\varepsilon_{c}\right)$

Interest rate semi-elasticity $\left(\varepsilon_{\mathrm{r}}\right)$

$1 /(v-1) \quad 1.00$

Technology and Capital Accumulation

Capital income share

Depreciation rate

Capital adjustment cost parameter

$\left(1-\sigma_{2}\right) /(1-\Gamma) \quad 1.00$

$1 /(1-\Gamma)(1-r) \quad 0.01$

Price Setting

Steady State Markup

$0 /(0-1) \quad 1.20$

Price Adjustment cost parameter

$\phi_{\mathrm{y}} \quad 85$

Monetary Policy

Autocorrelation of Money Growth Shocks

$\alpha \quad 0.33$

$\delta \quad(0.10)^{1 / 4}$

$\phi_{\mathrm{k}} \quad 10$

B. STEADY STATE

\begin{tabular}{lc}
\hline Description & $\begin{array}{c}\text { Values } \\
\text { (in annual terms) }\end{array}$ \\
\hline$\mu$ & 1.05 \\
$\mathrm{R}$ & 1.08 \\
$\mathrm{M} / \mathrm{B}$ & 0.33 \\
$\mathrm{~L}$ & 0.30 \\
$\mathrm{C} / \mathrm{Y}$ & 0.74 \\
$\mathrm{~K} / \mathrm{Y}$ & 2.50 \\
$\mathrm{I} / \mathrm{Y}$ & 0.25 \\
$\Phi / \mathrm{Y}$ & 0.20 \\
Price Adjust.Cost/Y $(\%)$ & 0.70 \\
Capital Adjust.Costs/I (\%) & 1.74 \\
\hline
\end{tabular}

